\title{
Influenza Vaccination for Secondary Prevention of Cardiovascular Events: A Systematic Review
}

\author{
Marlys H LeBras and Arden R Barry
}

\begin{abstract}
Background: Influenza is a common respiratory infection that may cause complications, including cardiovascular events. Influenza illness has been shown to double the risk of myocardial infarction, with the highest risk among patients with established cardiovascular disease. Vaccination against influenza has been associated with reductions in myocardial infarction, cerebrovascular disease, and death.
\end{abstract}

Objective: To evaluate the evidence for influenza vaccination as a strategy to reduce cardiovascular events specifically in patients with established cardiovascular disease.

Data Sources and Study Selection: MEDLINE, Embase, and the Cochrane Central Register of Controlled Trials were searched with the terms "influenza vaccine" and "cardiovascular disease". Included in this review were randomized controlled trials (RCTs), nonrandomized studies, and meta-analyses that compared influenza vaccination against control in patients with established cardiovascular disease and that reported clinically meaningful cardiovascular outcomes (defined as cardiovascular death, myocardial infarction, and stroke).

Data Extraction and Synthesis: The search yielded 10 studies (3 nonrandomized studies, 5 RCTs, and 2 meta-analyses). The nonrandomized studies and the RCTs had inconsistent results with respect to cardiovascular death and adverse cardiovascular events. The 2 meta-analyses, which included the same 4 RCTs involving patients with established cardiovascular disease, showed that the influenza vaccine reduced cardiovascular death by about $50 \%$ relative to control. Vaccination also reduced major cardiovascular events by about $43 \%$; the reduction was greater $(54 \%)$ in the subgroup of patients with recent $(\leq 1$ year) acute coronary syndrome. However, these data are potentially confounded by small sample sizes, low event rates, and variable outcome reporting. There was also high clinical heterogeneity among the studies, which may not reflect contemporary practice.

Conclusions: Given the limitations of these data, it is unclear whether the cardiovascular benefit with influenza vaccination in patients with cardiovascular disease is a true effect. Nevertheless, because of the potential benefit and the low risk of adverse events, the annual influenza vaccine should be recommended for all patients with established cardiovascular disease.

Keywords: influenza, vaccination, cardiovascular disease, secondary prevention

\section{RÉSUMÉ}

Contexte : La grippe est une infection courante des voies respiratoires qui peut causer des complications, notamment des événements cardiovasculaires. On a montré que la grippe double les risques d'infarctus du myocarde. De plus, les patients atteints d'une maladie cardiovasculaire sont les plus menacés. La vaccination contre la grippe a été associée à une réduction des cas d'infarctus du myocarde, de maladie cérébrovasculaire et de décès.

Objectif : Évaluer les données probantes montrant que la vaccination contre la grippe permet de réduire le nombre d'événements cardiovasculaires chez les patients déjà atteints d'une maladie cardiovasculaire.

Sources des données et sélection des études : Les bases de données MEDLINE et Embase et le Registre central Cochrane des essais aléatoires ont été interrogés en utilisant les termes " vaccin antigrippal » et " maladie cardiovasculaire ". Les études retenues pour la présente revue de la littérature devaient être des essais cliniques à répartition aléatoire, des essais cliniques non aléatoires ou des méta-analyses. De plus, elles devaient comparer les résultats de patients vaccinés contre la grippe et atteints d'une maladie cardiaque à ceux d'un groupe témoin qui étaient aussi atteints d'une maladie cardiaque. Enfin, elles devaient signaler des résultats cardiovasculaires cliniquement significatifs (définis comme un décès d'origine cardiovasculaire, un infarctus du myocarde ou un accident vasculaire cérébral).

Extraction et synthèse des données : Dix études répondaient aux critères de recherche (trois essais cliniques non aléatoires, cinq essais cliniques à répartition aléatoire et deux méta-analyses). Les essais cliniques non aléatoires et les essais cliniques à répartition aléatoire présentaient des résultats variables en ce qui touche aux décès d'origine cardiovasculaire et aux événements cardiovasculaires indésirables. Les deux méta-analyses, qui avaient en commun quatre essais cliniques à répartition aléatoire concernant des patients atteints d'une maladie cardiovasculaire, montraient que le vaccin contre la grippe permettait de réduire le nombre de décès d'origine cardiovasculaire d'environ $50 \%$ comparativement au groupe témoin. La vaccination a aussi réduit le nombre d'événements cardiovasculaires graves d'environ $43 \%$; le pourcentage était plus important $(54 \%)$ dans le sous-groupe de patients ayant récemment (à l'intérieur d'un an) souffert d'un syndrome coronarien aigu. Cependant, ces résultats sont potentiellement faussés par la petite taille des échantillons, les faibles taux d'événements et la variabilité avec laquelle on signale les résultats. Il y avait aussi une forte hétérogénéité clinique entre les études, ce qui pourrait ne pas être représentatif de la pratique actuelle. 
Can J Hosp Pharm. 2017;70(1):27-34

\section{INTRODUCTION}

$\mathrm{I}_{\mathrm{A}}^{\mathrm{n}}$ nfluenza is a respiratory infection caused primarily by influenza A and B viruses. ${ }^{1}$ Influenza infection not only causes the primary respiratory illness, but also can lead to severe secondary medical complications, such as viral pneumonia, bacterial pneumonia, and worsening of underlying medical conditions, including cancer, diabetes mellitus, and renal disease. ${ }^{2}$ Influenza is ranked among the top 10 infectious diseases affecting Canadians, ${ }^{2}$ with about $10 \%-20 \%$ of the population becoming infected each year. ${ }^{3}$ On average, 12200 hospital admissions and 3500 deaths related to influenza occur yearly in Canada. ${ }^{4-7}$ People at greatest risk of influenza-related complications are adults with underlying health conditions, including those with cardiac disorders. ${ }^{1}$ In Canada, influenza vaccination is recommended for all individuals aged 6 months and older who are considered at high risk, such as those with cardiovascular disease (CVD). ${ }^{1}$

Multiple observational studies have assessed cardiovascular $(\mathrm{CV})$ risk during the influenza season. Estimates from pooled data indicate that influenza infection, influenza-like illness, or respiratory tract infection doubles the risk of myocardial infarction (odds ratio [OR] 2.01, 95\% confidence interval [CI] $1.47-2.76),{ }^{8}$ and the highest risk is among those with established CVD. ${ }^{9}$ The mechanism by which influenza increases the risk of $\mathrm{CV}$ events is unclear, but may be related to triggering of rupture of vulnerable atherosclerotic plaques. ${ }^{10}$ Other contributing factors may involve impairment of the antiinflammatory properties of high-density lipoprotein cholesterol through increased macrophage infiltration, or the sequelae of acute infection (e.g., fever, tachycardia, dehydration). ${ }^{10-13}$

The influenza vaccine has been shown to reduce the risk of CV events, likely by reducing the risk of influenza infection. In observational trials, influenza vaccination has been associated with a decrease in the risk of myocardial infarction (OR 0.71 , 95\% CI 0.56-0.91), ${ }^{8}$ cerebrovascular disease (OR 0.77, 95\% CI 0.66-0.89), ${ }^{14}$ and all-cause death (OR 0.50, 95\% CI 0.46-0.55). ${ }^{14}$ However, in prospective randomized trials that included CV outcomes for safety assessment, influenza vaccination was not associated with a reduction in $\mathrm{CV}$ events, ${ }^{15-18}$ although these trials were limited by low event rates
Conclusions : En raison des limites de ces données, on ignore si le vaccin antigrippal offre réellement des effets cardiovasculaires bénéfiques pour les patients atteints d'une maladie cardiovasculaire. Néanmoins, compte tenu des avantages potentiels et du faible risque d'événements indésirables, le vaccin annuel contre la grippe doit être recommandé pour tous les patients atteints d'une maladie cardiovasculaire.

Mots clés : grippe, vaccination, maladie cardiovasculaire, prévention secondaire and potential for misclassification. ${ }^{19}$ Both the American Heart Association/American College of Cardiology and the European Society of Cardiology recommend the influenza vaccine annually for individuals with established $\mathrm{CVD}^{20-22}$ without specifically stating that the purpose is to reduce the risk of $\mathrm{CV}$ events. The objective of this systematic review was to evaluate the evidence for influenza vaccination as a strategy to reduce $\mathrm{CV}$ events in patients with established CVD.

\section{METHODS}

\section{Data Sources}

This review followed the Preferred Reporting Items for Systematic Reviews and Meta-Analyses (PRISMA) Statement. ${ }^{23}$ The following databases were queried, using the search terms "influenza vaccine" and "cardiovascular disease", from inception to February 2016: MEDLINE (including In-Process \& Other Non-Indexed Citations), Embase, and the Cochrane Central Register of Controlled Trials. A medical librarian was consulted to aid in search strategy and article retrieval. The search was limited to human studies published in English. The reference lists of identified articles were manually searched to identify other relevant articles. One author (M.H.L.) performed the database search.

\section{Study Selection}

Included were matched nonrandomized studies (cohort and case-control studies), randomized controlled trials (RCTs), and meta-analyses of randomized or nonrandomized studies. Included studies must have investigated influenza vaccination versus placebo or no treatment in patients with established CVD and must have reported clinically meaningful CV outcomes (defined as CV death, myocardial infarction, or stroke).

\section{Quality Assessment and Data Extraction}

Both authors independently performed the study selection, data extraction, and quality assessment. The following data were extracted from each study: design, inclusion criteria, number of participants, baseline characteristics, intervention, 
control, duration of follow-up, and $\mathrm{CV}$ outcomes (CV death and major adverse $\mathrm{CV}$ events [MACE], such as myocardial infarction or stroke). The quality of the included studies was assessed using Grading of Recommendations Assessment, Development and Evaluation (GRADE) criteria. $^{24,25}$ Any disagreement was resolved by discussion and consensus.

\section{RESULTS}

The database search yielded 452 citations, and 5 additional articles were identified from other sources (Figure 1). Fortyfour studies were assessed in full by both authors, of which 34 citations were removed primarily because of a lack of CV outcome reporting. The remaining 10 articles (3 nonrandomized studies, 5 RCTs, and 2 meta-analyses) were included in the qualitative analysis.

\section{Nonrandomized Studies}

Details of the nonrandomized studies are presented in Table $1{ }^{26-28}$ All 3 studies were deemed to be of low or very low quality according to the GRADE criteria.

Grau and others ${ }^{26}$ performed a case-control study of 370 consecutive cases with admission for ischemic or hemorrhagic stroke or transient ischemic attack who were matched 1:1 on the basis of age, sex, and area of residence with 370 randomly selected controls. At baseline, control patients had a significantly higher rate of influenza vaccination during the last campaign than did case patients (31\% versus 19\%) and also a significantly higher rate of 1 or more influenza vaccinations within the past 5 years ( $44 \%$ versus $28 \%$ ). Conversely, the case patients had higher rates of $\mathrm{CV}$ comorbidities than the controls, including hypertension ( $59 \%$ versus $41 \%$ ), diabetes ( $22 \%$ versus $13 \%$ ), hyperlipidemia (39\% versus $31 \%$ ), previous stroke (19\% versus $6 \%$ ), myocardial infarction (10\% versus $7 \%$ ), and current smoking (29\% versus 19\%). In the prespecified subgroup of patients with previous vascular disease, influenza vaccination was associated with a reduction in stroke or transient ischemic attack in an unadjusted analysis (OR 0.47, 95\% CI 0.29-0.76); this result remained significant with adjustment for hypertension,

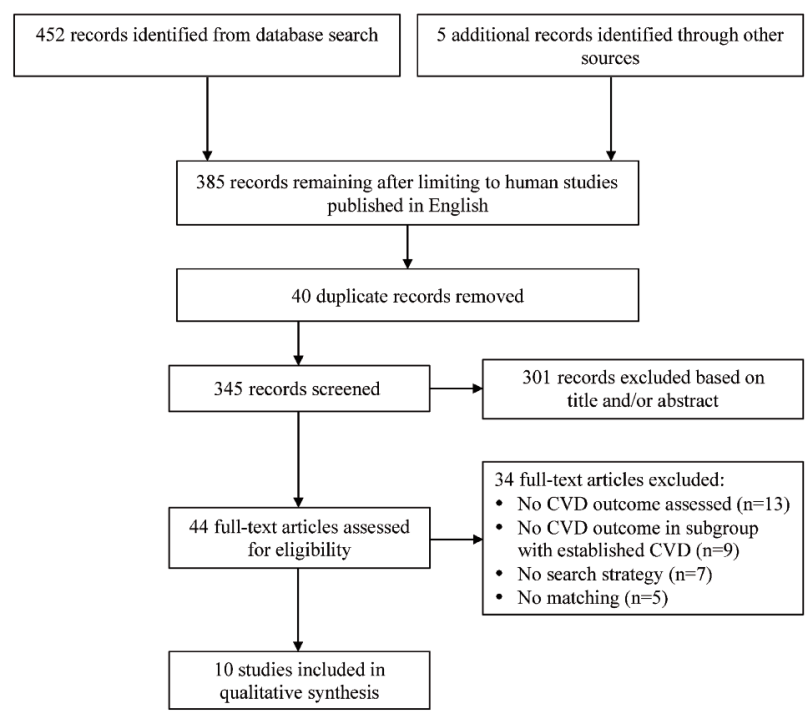

Figure 1. Preferred Reporting Items for Systematic Reviews and Meta-Analyses (PRISMA) study flow diagram. CVD = cardiovascular disease.

alcohol abstinence, high alcohol consumption, and current sports participation (adjusted OR 0.45, 95\% CI 0.26-0.76).

Heffelfinger and others ${ }^{27}$ performed a case-control study in a health maintenance organization in Seattle, Washington. Included were 750 cases (women or hypertensive men) aged 65-79 years with fatal or nonfatal myocardial infarction who were matched by sex, age category, calendar year, and presence of pharmacologically treated hypertension to 1735 controls from a stratified random sample. Cardiovascular disease was more common among the cases than the controls (31\% versus $17 \%, p<0.001$ ), as were diabetes ( $23 \%$ versus $10 \%, p<0.001$ ) and current smoking $(16 \%$ versus $10 \%, p<0.001)$. In the subgroup of patients with pre-existing CVD, a multivariable analysis (adjusted for age, sex, history of treated hypertension, and index year) showed no association between influenza vaccination and incident myocardial infarction (adjusted OR $1.71,95 \%$ CI 0.99-2.96).

Table 1. Summary of Nonrandomized Trials

\begin{tabular}{|c|c|c|c|c|c|c|c|}
\hline Study (Year) & $\begin{array}{l}\text { GRADE } \\
\text { Score }\end{array}$ & Design & $\begin{array}{l}\text { No. of } \\
\text { Patients }\end{array}$ & $\begin{array}{c}\text { Baseline } \\
\text { Characteristics }\end{array}$ & Exposed & Non-exposed & Duration \\
\hline $\begin{array}{l}\text { Grau et al. } \\
(2005)^{26}\end{array}$ & Very low & $\begin{array}{l}\text { Matched } \\
\text { case- } \\
\text { control }\end{array}$ & 740 & $\begin{array}{l}\text { Mean age } \\
61 \text { years, } \\
69 \% \text { male }\end{array}$ & $\begin{array}{c}\text { Influenza } \\
\text { vaccination }\end{array}$ & $\begin{array}{l}\text { No influenza } \\
\text { vaccination }\end{array}$ & 18 months \\
\hline $\begin{array}{l}\text { Heffelfinger et al. } \\
(2006)^{27}\end{array}$ & Low & $\begin{array}{l}\text { Matched } \\
\text { case-- } \\
\text { control }\end{array}$ & 2485 & $\begin{array}{l}\text { Median age } \\
73 \text { years, } \\
33 \% \text { male }\end{array}$ & $\begin{array}{l}\text { Influenza } \\
\text { vaccination }\end{array}$ & $\begin{array}{l}\text { No influenza } \\
\text { vaccination }\end{array}$ & 6 years \\
\hline $\begin{array}{l}\text { Lavallée et al. } \\
(2014)^{28}\end{array}$ & Low & $\begin{array}{l}\text { Propensity } \\
\text { score } \\
\text { matched } \\
\text { cohort }\end{array}$ & 10108 & $\begin{array}{l}\text { Mean age } \\
70 \text { years, } \\
60 \% \text { male }\end{array}$ & $\begin{array}{l}\text { Influenza } \\
\text { vaccination }\end{array}$ & $\begin{array}{l}\text { No influenza } \\
\text { vaccination }\end{array}$ & 2 years \\
\hline
\end{tabular}


Lavallée and others ${ }^{28}$ performed a propensity scorematched cohort study of 10108 patients (50\% vaccinated, $50 \%$ unvaccinated) with recent ( 8 days to $<6$ months) ischemic stroke or transient ischemic attack using data from 3 prospective studies. For most of the patients (88\%), stroke was the qualifying event. Statins were used by about $70 \%$ of patients, angiotensin-modulating agents by $65 \%$, acetylsalicylic acid (ASA) by $60 \%$, and $B$-blockers by $26 \%$. The prespecified subgroup analysis of patients with a history of coronary artery disease $(n=1784)$ did not show an association between influenza vaccination and MACE, which included cardiac death, nonfatal MI, and nonfatal stroke (hazard ratio [HR] 1.08, 95\% CI 0.63-1.86), as well as fatal or nonfatal myocardial infarction (HR 1.67, 95\% CI 0.40-6.97) and fatal or nonfatal stroke (HR $0.95,95 \%$ CI $0.51-1.78$ ).

\section{Randomized Controlled Trials}

Details of the RCTs are presented in Table 2. ${ }^{29-34}$ Two of the RCTs were assessed to be of moderate quality and one was of low quality according to the GRADE criteria; quality assess- ment could not be performed for the remaining 2 RCTs, which have not been formally published in full-text.

The FLUVACS pilot study enrolled 301 patients with coronary artery disease who were randomly assigned to receive the seasonal influenza vaccine or placebo. ${ }^{29}$ More patients in the vaccination group than the placebo group presented with ST-segment elevation myocardial infarction (STEMI) $(47 \%$ versus $37 \%$ ), whereas fewer patients in the vaccination group presented with non-ST-segment elevation myocardial infarction (NSTEMI) (53\% versus 63\%). Among all of the patients with STEMI, 57\% did not receive primary percutaneous coronary intervention (PCI) or fibrinolytic therapy, whereas $88 \%$ of the patients with NSTEMI received early conservative therapy. The use of $ß$-blockers ( $64 \%$ of patients), angiotensin-converting enzyme (ACE) inhibitors (57\%), and statins (34\%) was relatively low. All of the patients received ASA. Overall, CV death was lower at 6 months among those who received influenza vaccination ( $2 \%$ versus $8 \%$, relative risk [RR] 0.25 , 95\% CI 0.07-0.86), as was the composite of MACE, defined as $\mathrm{CV}$ death, nonfatal $\mathrm{MI}$, or rehospitalization for ischemia

Table 2. Summary of Randomized Controlled Trials

\begin{tabular}{|c|c|c|c|c|c|c|c|c|}
\hline Study (Year) & $\begin{array}{l}\text { GRADE } \\
\text { Score }\end{array}$ & Design & Country & $\begin{array}{l}\text { No. of } \\
\text { Patients }\end{array}$ & $\begin{array}{c}\text { Baseline } \\
\text { Characteristics }\end{array}$ & Intervention & Control & Duration \\
\hline $\begin{array}{l}\text { FLUVACS }(2002 \\
\text { and 2004) }\end{array}$ & Low & $\begin{array}{l}\text { Randomized, } \\
\text { single-blind }\end{array}$ & Argentina & 301 & $\begin{array}{l}\text { Mean age } \\
65 \text { years, } \\
66 \% \text { with acute } \\
\text { MI, } 34 \% \text { with } \\
\text { elective PCl }\end{array}$ & $\begin{array}{l}\text { Single } 0.5-\mathrm{mL} \\
\text { IM dose of } \\
\text { A/Moscow/ } \\
\text { 10/99-like virus, } \\
\text { A/New Caledonia/ } \\
\text { 20/99 (H1N1)-like } \\
\text { virus, and } \\
\text { AB/Sichuan/ } \\
\text { 379/99-like virus }\end{array}$ & Saline & 6 months \\
\hline$\overline{\text { FLUCAD }(2008)^{31}}$ & Moderate & $\begin{array}{l}\text { Randomized, } \\
\text { double-blind }\end{array}$ & Poland & 658 & $\begin{array}{l}\text { Median age } \\
60 \text { years, } \\
73 \% \text { male, } \\
56 \% \text { with stable } \\
\text { CAD, } 24 \% \text { with } \\
\text { PCI for ACS, } \\
20 \% \text { with PCI } \\
\text { for stable angina }\end{array}$ & $\begin{array}{l}\text { Single 0.5-mL } \\
\text { IM dose of } \\
\text { A/New } \\
\text { Caledonia/ } \\
\text { 20/99 (H1N1), } \\
\text { A/Christchurch/ } \\
\text { 28/03 (H3N2), } \\
\text { and B/Jiangsu/ } \\
\text { 10/03 }\end{array}$ & Placebo & 14 months \\
\hline $\begin{array}{l}\text { Phrommintikul } \\
\text { et al. }(2011)^{32}\end{array}$ & Moderate & $\begin{array}{c}\text { Randomized, } \\
\text { open-label }\end{array}$ & Thailand & 439 & $\begin{array}{l}\text { Mean age } \\
66 \text { years, } \\
57 \% \text { male, } \\
47 \% \text { NSTEMI, } \\
36 \% \text { STEMI, } \\
16 \% \text { with } \\
\text { unstable angina }\end{array}$ & $\begin{array}{l}\text { Single } 0.5-\mathrm{mL} \\
\text { IM dose of split, } \\
\text { inactivated } \\
\text { influenza vaccine } \\
\text { (type not } \\
\text { reported) }\end{array}$ & $\begin{array}{c}\text { No } \\
\text { treatment }\end{array}$ & 12 months \\
\hline$\overline{I V C A D ~(2009)^{33}}$ & NA & $\begin{array}{l}\text { Randomized, } \\
\text { single-blind }\end{array}$ & Iran & 281 & NR & $\begin{array}{l}\text { Single } 0.5-\mathrm{mL} \\
\text { IM dose of } \\
2007 / 2008 \\
\text { influenza vaccine }\end{array}$ & Placebo & 6 months \\
\hline$\overline{F L U V A C S-I C * 34}$ & NA & $\begin{array}{l}\text { Randomized, } \\
\text { single-blind }\end{array}$ & Argentina & 117 & NR & $\begin{array}{l}\text { Single IM dose of } \\
\text { influenza vaccine }\end{array}$ & $\begin{array}{c}\text { Conventional } \\
\text { medical } \\
\text { therapy }\end{array}$ & 6 months \\
\hline
\end{tabular}

ACS = acute coronary syndrome; CAD = coronary artery disease; GRADE = Grading of Recommendations Assessment Development and Evaluation; IM = intramuscular; $\mathrm{MI}=$ myocardial infarction; $\mathrm{NA}=$ not applicable; NR = not reported; NSTEMI = non-ST-segment elevation myocardial infarction; $\mathrm{PCI}=$ percutaneous coronary intervention; STEMI = ST-segment elevation myocardial infarction.

*Study was completed, but study results have not been published. 
( $11 \%$ versus $23 \%$, RR $0.50,95 \%$ CI $0.29-0.85$ ). Vaccination lowered the risk of MACE in the myocardial infarction subgroup (RR 0.42, 95\% CI 0.21-0.83), but not in the elective PCI subgroup. No cases of influenza illness were reported in either group. Overall adverse events were not reported as an outcome. In a 1-year follow-up study, the rates of 2 specific outcomes were lower in the vaccinated group than the placebo group: $\mathrm{CV}$ death $(6 \%$ versus $17 \%$, RR $0.34,95 \%$ CI $0.17-0.71)$ and MACE (22\% versus $37 \%$, RR $0.59,95 \%$ CI $0.40-0.86) .{ }^{30}$

The FLUCAD trial compared influenza vaccination with placebo in 658 patients with confirmed coronary artery disease. ${ }^{31}$ Patients had high utilization (> 90\%) of secondary $\mathrm{CV}$ preventive medications, including ASA, statins, B-blockers, and ACE inhibitors, and about $50 \%$ were taking a thienopyridine. Influenza-like illness was reported more frequently in the unvaccinated group than in the vaccinated group (13\% versus $8 \%, p=0.042)$. At 12 months, there was no difference in CV death (HR 1.06, 95\% CI 0.15-7.56) or MACE, defined as CV death, acute MI, or coronary revascularization (HR 0.54, 95\% CI 0.24-1.21). However, the composite of MACE or hospitalization for myocardial ischemia was lower with vaccination (HR 0.54, 95\% CI 0.29-0.99). No severe adverse events were reported, and less than $5 \%$ of patients in both groups experienced minor, local, or generalized transient adverse effects.

Phrommintikul and others ${ }^{32}$ studied 439 patients admitted to hospital with acute coronary syndrome, who were randomly assigned to receive the influenza vaccine or no treatment. Of the patients who presented with STEMI, 43\% received fibrinolytic therapy, 33\% underwent primary $\mathrm{PCI}$, and $23 \%$ received no reperfusion therapy. About $50 \%$ of patients who presented with NSTEMI had no revascularization. At baseline, $97 \%$ of the patients were taking ASA, $84 \%$ a statin, $74 \%$ a B-blocker, and $59 \%$ an angiotensin-modulating agent. Influenza-like illness rates were not reported. The primary outcome of MACE (defined as death or hospitalization for acute coronary syndrome, heart failure, or stroke) was lower with vaccination than with no treatment $(9.5 \%$ versus $19.3 \%$, unadjusted HR $0.70,95 \%$ CI $0.57-0.86$ ), a result that was driven primarily by a reduction in hospitalization for acute coronary syndrome. Cardiovascular death was not significantly different between groups (HR 0.39, 95\% CI 0.14-1.12). After adjustment for age, sex, serum creatinine, ACE inhibitor treatment, and coronary revascularization, MACE remained significantly lower with vaccination (adjusted HR 0.67, 95\% CI 0.51-0.86). There were no hospital admissions secondary to adverse effects of the influenza vaccine; however, other adverse events were not reported.

The IVCAD trial was presented in abstract form at the 19th European Congress of Clinical Microbiology and Infectious Diseases in $2009 .{ }^{33}$ A total of 281 patients with coronary artery disease were randomly assigned to receive influenza vaccine or placebo. At 6 months, CV death was not significantly different between the groups. As well, the authors stated that none of the secondary outcomes (angina severity, coronary artery stenosis score, cardiac ejection fraction, or cardiac adverse events) were "markedly different" between groups. However, there was a significantly higher rate of at least one adverse cardiac event (acute coronary syndrome, coronary revascularization, or CV death) in the placebo group (rates not provided). Patients in the placebo group had a higher rate of influenza infection $(p=0.049)$, but no other adverse events were reported.

The FLUVACS-IC study was completed in March 2008. However, it has not been published, and information is available only through the Clinicaltrials.gov website (NCT00664339). ${ }^{34}$ In this study, 117 patients with New York Heart Association class III-IV heart failure requiring ventilator support (without endotracheal intubation) and high-dose loop diuretic therapy were randomly assigned to receive influenza vaccination or conventional therapy. At 6 months, CV death was reduced in the vaccination group (3\% versus $17 \%$, $p=0.022)$, as was all-cause death or rehospitalization $(33 \%$ versus $74 \%, p<0.001)$. No major adverse cardiac events were reported.

\section{Meta-Analyses}

A meta-analysis by Udell and others ${ }^{35}$ included 12 RCTs that compared influenza vaccination with placebo or standard of care, 4 of which ${ }^{29,31-33}$ included a total of 1655 patients with pre-existing CVD. The primary outcome was a composite of MACE (defined as CV death or hospitalization for myocardial infarction, unstable angina, stroke, heart failure, or urgent coronary revascularization). The mean age across these 4 RCTs was about 62 years, and roughly two-thirds were male. Followup ranged from 10 to 12 months. In the prespecified CVD subgroup, influenza vaccine significantly reduced both MACE (risk ratio $0.57,95 \% \mathrm{CI} 0.41-0.79, I^{2}=14 \%$ ) and $\mathrm{CV}$ death (risk ratio $0.50,95 \% \mathrm{CI} 0.27-0.95, I^{2}=15 \%$ ). In the prespecified subgroup of patients with recent ( $\leq 1$ year) acute coronary syndrome $(n=815)$, influenza vaccine significantly reduced MACE (risk ratio $0.46,95 \%$ CI $0.33-0.64, I^{2}=0 \%$ ) but not CV death (risk ratio $0.44,95 \%$ CI $0.17-1.15, I^{2}=38 \%$ ). There was no difference in MACE or CV death in the prespecified subgroup of patients with stable coronary artery disease $(n=840)$.

A subsequent Cochrane Collaboration meta-analysis of 8 RCTS by Clar and others ${ }^{36}$ included the same 4 RCTs, but had a total of 1682 patients with CVD. Follow-up for these patients ranged from 10 to 12 months. As with the metaanalysis by Udell and others, ${ }^{35} \mathrm{CV}$ death was significantly reduced with influenza vaccine (risk ratio $0.44,95 \%$ CI $0.26-$ $\left.0.76, I^{2}=0 \%\right)$. However, there was no difference in $\mathrm{CV}$ death 
in the subgroup of patients with acute coronary syndrome $(n=350)$ (risk ratio $0.46,95 \%$ CI $\left.0.04-5.20, I^{2}=58 \%\right)$ or stable angina and elective PCI $(n=602)$ (risk ratio $0.35,95 \%$ CI $\left.0.07-1.73, I^{2}=0 \%\right)$. The authors stated that they were unable to perform a meta-analysis for other $\mathrm{CV}$ events because of variable outcome reporting among the studies.

\section{DISCUSSION}

The highest level of evidence identified in this systematic review showed that, in patients with established CVD, influenza vaccine reduced CV death by a relative $50 \%-56 \%$, a conclusion based on 2 meta-analyses that included the same 4 RCTs. Furthermore, influenza vaccination reduced MACE by a relative $43 \%$, although this result was reported in only 1 of the 2 meta-analyses. A subgroup analysis demonstrated that the reduction in MACE was significant only among patients with recent acute coronary syndrome, not those with stable coronary artery disease. Despite including the same 4 RCTs, the total number of patients and the results of the 2 meta-analyses were similar but not identical. The relatively small sample sizes and event rates in the original studies, as well as variable outcome reporting, may explain the inconsistent results. The current systematic review highlights the lack of high-quality data investigating the effect of influenza vaccine in patients with CVD. It is acknowledged that the conclusions of this review rely almost entirely on the quality of the 2 metaanalyses because of the lack of additional RCTs identified and the limitations of the nonrandomized data.

It is difficult to reconcile the magnitude of the effect, given that the 2 highest-quality RCTs individually did not show a reduction in CV death. ${ }^{31,32}$ However, both of these RCTs enrolled a small number of patients, and thus may not have been sufficiently powered to detect a difference. Furthermore, small sample sizes may introduce confounding and bias, which may have resulted in overestimation of the true benefit for the RCTs with positive results. However, 2 independently performed meta-analyses calculated a similar relative risk reduction for $\mathrm{CV}$ death with minimal statistical heterogeneity ( $\left.I^{2} \leq 15 \%\right)$ among patients with established CVD. Despite low statistical heterogeneity, there was marked clinical heterogeneity among the RCTs because of different study locations and practices, inclusion criteria, use of revascularization and secondary $\mathrm{CV}$ preventive medications, and composition of the influenza vaccine. It is challenging to assess publication bias because of the small number of trials included in each metaanalysis. ${ }^{37,38}$ The funnel plot in the meta-analysis by Udell and others $^{35}$ suggested that small trials with CV benefit may remain unpublished; Clar and others ${ }^{36} \mathrm{did}$ not assess publication bias in their meta-analysis.

In general, the identified RCTs were limited by small sample sizes, limited power, and imprecise effect estimates.
Additionally, 2 of the 5 RCTs have not been formally published (and thus have not undergone peer review), and the limited information available on these studies (in the form of an abstract or trial registration) did not report many key aspects of study design and results. Furthermore, follow-up in most trials was limited to the influenza season (6 months on average), and there were no long-term data for patients receiving multiple influenza vaccinations over several years. Overall, adverse effects were not consistently reported; however, most were generally minor and transient. Other trials have reported a low incidence of adverse effects $(0 \%-3 \%)$ and no significant difference in serious adverse events between influenza vaccine and placebo. ${ }^{15-17}$ Of the RCTs, FLUCAD ${ }^{31}$ was likely the most well designed. The authors attempted to minimize bias and confounding through appropriate randomization, use of intention-to-treat analyses, and minimal loss to follow-up. As well, it was the only doubleblind RCT identified in the literature search. This study was more reflective of modern practice than the others, as all patients who presented with acute coronary syndrome underwent PCI, and there was high utilization of secondary CV preventive medications. Although the results were neutral, the outcomes of CV death and MACE were likely underpowereda post hoc sample-size calculation by the study's authors showed that more than 2000 patients would have been needed to show statistical significance.

The nonrandomized trial data offer little value beyond the RCT data because of methodologic limitations and inconsistent results. In the highest-quality nonrandomized trial, conducted by Lavallée and others, ${ }^{28}$ the influenza vaccine had a neutral effect on the subgroup of patients with coronary artery disease. Although propensity score matching was used to minimize differences between groups, and CV events were adjudicated in a blinded manner in 2 of the 3 studies that constituted the cohort in this study, exposure status was limited by potential misclassification bias due to patient self-reporting of vaccination status (which is subject to recall bias). Furthermore, the study was likely underpowered because of the small proportion of patients with a history of CVD. The 2 matched case-control studies $^{26,27}$ were heterogeneous with regard to results: one showed a benefit with influenza vaccine, whereas the other was neutral. However, both of these studies were limited by differences in baseline characteristics that were not adjusted for in the analyses. As well, misclassification of cases may have occurred through patient self-reporting of vaccination status or errors in electronic health records.

Two RCTs assessing the effect of influenza vaccination on MACE in patients with heart failure (NCT01945268) ${ }^{39}$ and established CVD (NCT00679237) ${ }^{40}$ were in progress at the time of writing, with final data collection and study completion anticipated in December 2016 and December 2019, respectively. 
Pharmacists in both community- and hospital-based practices are in an ideal position to provide influenza vaccination to patients, owing to their knowledge base and accessibility. Canadian legislation now permits pharmacists with proper certification to administer influenza vaccination to patients in 9 of the 10 provinces. ${ }^{41}$ Pharmacists should use this opportunity to identify patients with established CVD (particularly those with recent acute coronary syndrome) and to educate them about the reduction in $\mathrm{CV}$ death $(53 \%$ relative risk reduction, $2.9 \%$ absolute risk reduction, number needed to treat 35 ) and $\mathrm{CV}$ events (43\% relative risk reduction, $7.4 \%$ absolute risk reduction, number needed to treat 14 ) with the influenza vaccine over approximately one influenza season.

\section{CONCLUSION}

Influenza vaccination may be an effective strategy for reducing $\mathrm{CV}$ events in patients with pre-existing CVD. RCTs have had inconsistent results with respect to $\mathrm{CV}$ death and MACE because of small sample sizes, low event rates, and potential confounding and bias. However, meta-analyses of RCTs showed that the influenza vaccine reduced both CV death and MACE, relative to control, by about $50 \%$. Given the limitations of the data, it is unclear whether this is a true effect. Nevertheless, because of the potential benefit and the low risk of adverse events, the annual influenza vaccine should be recommended for all patients with established CVD. Pharmacists can aid in identifying patients with established CVD who may benefit from the influenza vaccine, can educate patients about the potential CV benefits, and, with approved training, can provide the immunization.

\section{References}

1. National Advisory Committee on Immunization (NACI). Canadian Immunization Guide chapter on influenza and statement on seasonal influenza vaccine for 2016-2017. Ottawa (ON): Public Health Agency of Canada; [modified 2016 Oct 18; cited 2017 Jan 13]. Available from: www.phac-aspc.gc.ca/naci-ccni/flu-2016-grippe-eng.php

2. Kwong JC, Ratnasingham S, Campitelli MA, Daneman N, Deeks SL, Manuel DG, et al. The impact of infection on population health: results of the Ontario burden of infectious diseases study. PLoS One. 2012; 7(9):e44103.

3. Immunization, vaccines and biologicals: influenza. Geneva (Switzerland): World Health Organization; [updated 2008 Jan 25; cited 2016 Mar 26]. Available from: www.who.int/immunization/topics/influenza/en/

4. Schanzer DL, McGeer A, Morris K. Statistical estimates of respiratory admissions attributable to seasonal and pandemic influenza for Canada. Influenza Other Respir Viruses. 2013;7(5):799-808.

5. Schanzer DL, Sevenhuysen C, Winchester B, Mersereau T. Estimating influenza deaths in Canada, 1992-2009. PLoS One. 2013;8(11):e80481.

6. Schanzer DL, Langley JM, Tam TWS. Role of influenza and other respiratory viruses in admissions of adults to Canadian hospitals. Influenza Other Respir Viruses. 2008;2(1):1-8.

7. Schanzer DL, Langley JM, Tam TW. Hospitalization attributable to influenza and other viral respiratory illnesses in Canadian children. Pediatr Infect Dis J. 2006;25(9):795-800.

8. Barnes M, Heywood AE, Mahimbo A, Rahaman B, Newall AN, Macintyre CR. Acute myocardial infarction and influenza: a meta-analysis of casecontrol studies. Heart. 2015;101(21):1738-47.
9. Naghavi M, Barlas Z, Siadaty S, Naquib S, Madjid M, Casscells W. Association of influenza vaccination and reduced risk of recurrent myocardial infarction. Circulation. 2000;102(25):3039-45.

10. Loomba RS, Aggarwal S, Shah PH, Arora RR. Influenza vaccination and cardiovascular morbidity and mortality: analysis of 292,383 patients. J Cardiovasc Pharmacol Ther. 2012;17(4):277-83.

11. Bratincsák A, El-Said HG, Bradley JS, Shayan K, Grossfeld PD, Cannavino CR. Fulminant myocarditis associated with pandemic H1N1 influenza A virus in children. J Am Coll Cardiol. 2010;55(9):928-9.

12. Muhammad S, Haasbach E, Kotchourko M, Strigli A, Krenz A, Ridder DA, et al. Influenza virus infection aggravates stroke outcome. Stroke. 2011; 42(3):783-91

13. Corrales-Medina VF, Musher DM, Shachkina S, Chirinos JA. Acute pneumonia and the cardiovascular system. Lancet. 2013;381(9865):496-505.

14. Nicol KL, Nordin J, Mullooly J, Lask R, Fillbrandt K, Iwane M. Influenza vaccination and reduction in hospitalizations for cardiac disease and stroke among the elderly. N Engl J Med. 2003;348(14):1322-32.

15. Langley JM, Risi G, Caldwell M, Gilderman L, Berwald B, Fogarty C, et al. Dose-sparing H5N1 A/Indonesia/05/2005 pre-pandemic influenza vaccine in adults and elderly adults: a phase III, placebo-controlled, randomized study. J Infect Dis. 2011;203(12):1729-38.

16. Wu J, Li W, Wang HQ, Chen JT, Lv M, Zhou JC, et al. A rapid immune response to 2009 influenza $\mathrm{A}(\mathrm{H} 1 \mathrm{~N} 1)$ vaccines in adults: a randomized, double-blind, controlled trial. J Infect Dis. 2010;202(5):675-80.

17. De Villiers PJT, Steele AD, Hiemstra LA, Rappaport R, Dunning AJ, Gruber WC, et al.; LAIV Elderly Study Trial Network. Efficacy and safety of a live attenuated influenza vaccine in adults 60 years of age and older. Vaccine. 2009;28(1):228-34.

18. Govaert TM, Thijs CT, Masurel N, Sprenger MJ, Dinant GJ, Knottnerus JA. The efficacy of influenza vaccination in elderly individuals. A randomized double-blind placebo-controlled trial. JAMA. 1994;272(21):1661-5.

19. Singh S, Loke YK. Drug safety assessment in clinical trials: methodological challenges and opportunities. Trials. 2012;13:138.

20. Davis MM, Taubert K, Benin AL, Brown DW, Mensah GA, Baddour LM, et al. Influenza vaccination as secondary prevention for cardiovascular disease: a science advisory from the American Heart Association/American College of Cardiology. Circulation. 2006;114(14):1549-53.

21. Van de Werf F, Bax J, Betriu A, Blomstrom-Lundqvist C, Crea F, Falk V, et al.; ESC Committee for Practice Guidelines. Management of acute myocardial infarction in patients presenting with persistent ST-segment elevation: the Task Force on the Management of ST-Segment Elevation Acute Myocardial Infarction of the European Society of Cardiology. Eur Heart J. 2008; 29(23):2909-45.

22. Perk J, De Backer G, Gohlke H, Graham I, Reiner Z, Verschuren M, et al.; European Association for Cardiovascular Prevention \& Rehabilitation; ESC Committee for Practice Guidelines. European guidelines on cardiovascular disease prevention in clinical practice (version 2012). The Fifth Joint Task Force of the European Society of Cardiology and Other Societies on Cardiovascular Disease Prevention in Clinical Practice (constituted by representatives of nine societies and by invited experts). Eur Heart J. 2012; 33(13):1635-701.

23. Moher D, Liberati A, Tetzlaff J, Altman DG; PRISMA Group. Preferred reporting items for systematic reviews and meta-analyses: the PRISMA statement. PLoS Med. 2009;6(7):e1000097.

24. Guyatt GH, Oxman AD, Kunz R, Vist GE, Falck-Ytter Y, Schünemann HJ; GRADE Working Group. GRADE: What is "quality of evidence" and why is it important to clinicians? BMJ. 2008;336(7651):995-8.

25. Balshem H, Helfand M, Schünemann HJ, Oxman AD, Kunz R, Brozek J, et al. GRADE guidelines: 3. Rating the quality of evidence. J Clin Epidemiol. 2011;64(4):4016.

26. Grau AJ, Fischer B, Barth C, Ling P, Lichy C, Buggle F. Influenza vaccination is associated with a reduced risk of stroke. Stroke. 2005;36(7):1501-6.

27. Heffelfinger JD, Heckbert SR, Psaty BM, Weiss NS, Thompson WW, Bridges $\mathrm{CB}$, et al. Influenza vaccination and risk of incident myocardial infarction. Hum Vaccin. 2006;2(4):161-6.

28. Lavallée PC, Labreuche J, Fox KM, Lavados P, Mattle H, Steg PG, et al.; PERFORM, OPTIC, and AMISTAD Investigators. Influenza vaccination 
and cardiovascular risk in patients with recent TIA and stroke. Neurology. 2014;82(21):1905-13

29. Gurfinkel EP, de la Fuente RL, Mendiz O, Mautner B. Influenza vaccine pilot study in acute coronary syndromes and planned percutaneous coronary interventions: the FLU Vaccination Acute Coronary Syndromes (FLUVACS) Study. Circulation. 2002;105(18):2143-7.

30. Gurfinkel EP, Leon de la Fuente R, Mendiz O, Mautner B. Flu vaccination in acute coronary syndromes and planned percutaneous coronary interventions (FLUVACS) study. Eur Heart J. 2004;25(1):25-31.

31. Ciszewski A, Bilinska ZT, Brydak LB, Kepka C, Kruk M, Romanowska M, et al. Influenza vaccination in secondary prevention from coronary ischaemic events in coronary artery disease: FLUCAD study. Eur Heart J. 2008; 29(11):1350-8.

32. Phrommintikul A, Kuanprasert S, Wongcharoen W, Kanjanavanit R, Chaiwarith R, Sukonthasarn A. Influenza vaccination reduces cardiovascular events in patients with acute coronary syndrome. Eur Heart J. 2011; 32(14):1730-5.

33. Keshtkar-Jahromi M, Vakili H, Rahnavardi M, et al. The efficacy of influenza vaccination in reducing cardiovascular events in patients with coronary artery diseases: IVCAD study [abstract]. Clin Microbiol Infect. 2009;15 Suppl 4:S395-6.

34. Flu vaccination in congestive heart failure (FLUVACS-IC) [study registration]. US National Institutes of Health, Clinicaltrials.gov; 2008 Apr 17 [cited 2016 Mar 26]. Available from: https://clinicaltrials.gov/ ct2/show/NCT00664339

35. Udell JA, Zawi R, Bhatt DL, Keshtkar-Jahromi M, Gaughran F, Phrommintikul A, et al. Association between influenza vaccination and cardiovascular outcomes in high-risk patients: a meta-analysis. JAMA. 2013; 310:1711-20

36. Clar C, Oseni Z, Flowers N, Keshtkar-Jahromi M, Rees K. Influenza vaccines for preventing cardiovascular disease. Cochrane Database Syst Rev. 2015;(5): CD005050.

37. Ioannidis JPA, Trikalinos TA. The appropriateness of asymmetry tests for publication bias in meta-analyses: a large survey. CMAJ. 2007;176(8):1091-6.

38. Sterne JAC, Egger M, Moher D. Addressing reporting biases. In: Higgins JPT, Green S, editors. Cochrane handbook for systematic reviews of interventions. Version 5.0.0. Oxford (UK): Cochrane Collaboration; 2008.
39. Influenza vaccine to prevent adverse vascular events: pilot (IVVE:Pilot) [study registration]. US National Institutes of Health, Clinicaltrials.gov; 2013 Sep 13 [cited 2016 Jul 12]. Available from: https://clinicaltrials.gov/ct2/show/ NCT01945268

40. Risk reduction in coronary heart disease (SPREK!) [study registration]. US National Institutes of Health, Clinicaltrials.gov; 2007 Jul 5 [cited 2016 Jul 12]. Available from: https://clinicaltrials.gov/ct2/show/NCT00679237

41. Pharmacist's role in flu vaccination. Ottawa (ON): Canadian Pharmacists Association; [cited 2016 Jun 26]. Available from: https://www.pharmacists.ca/ education-practice-resources/patient-care/influenza-resources/pharmacistsrole-in-flu-vaccination

Marlys H LeBras, BSP, PharmD, ACPR, was, at the time of writing, with the Faculty of Pharmaceutical Sciences, The University of British Columbia, Vancouver, British Columbia. She is now with the RxFiles Academic Detailing Program, Saskatoon Health Region, Saskatoon, Saskatchewan.

Arden R Barry, BSC, BSC(Pharm), PharmD, ACPR, is with the Chilliwack General Hospital, Lower Mainland Pharmacy Services, Chilliwack, British Columbia, and the Faculty of Pharmaceutical Sciences, The University of British Columbia, Vancouver, British Columbia.

Competing interests: None declared.

Address correspondence to:

Dr Arden R Barry

Faculty of Pharmaceutical Sciences

The University of British Columbia

2405 Wesbrook Mall

Vancouver BC V6T 1 Z3

e-mail: arden.barry@ubc.ca

Funding: None received.

Acknowledgements: The authors thank Marisa MacDonald, MLIS, Librarian, Chilliwack General Hospital, for her help with conducting the literature search.

\section{$\square$ C $\mathrm{CSHP}$}

\section{CSHP Members Save on} ASHP and Pharmaceutical Press Publications!

CSHP members are invited to place their orders for all ASHP and Pharmaceutical Press

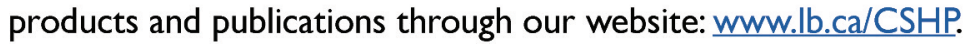

\section{CSHP members also save on cross border shipping charges through Login Canada!}

CSHP members can obtain the password needed to place an order for ASHP, Pharmaceutical Press, and other products and publications by going to the Products and Publications tab on the CSHP homepage. From there, please scroll down to Products and Other Publications and select ASHP/ Pharmaceutical Press. Members will be asked to login before being allowed to proceed to CSHP's virtual bookstore.

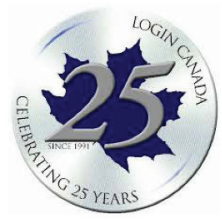

